\title{
FIRST RECORD OF THE STONECAT IN SASKATCHEWAN WATERS
}

LEROY M. ROYER, Kelsey Institute of Applied Arts and Sciences, Saskatoon, Saskatchewan, and

C. BLAINE ANDERSON, Box 310, Shaunavon, Saskatchewan

Members of the catfish family (Ictaluridae) are not common or widespread in Saskatchewan waters. Three species, the black bullhead (Ictalurus melas), the brown bullhead ( $I$. nebulosus) and the tadpole madtom (Noturus gyrinus) are reported by Scott and Crossman (1973) to occur in the Souris River basin of southeastern Saskatchewan.

In July, 1975, Mr. Anderson collected several specimens of the stonecat (Noturus flavus) while completing a fish collection as part of the course work for the Renewable Resources Technology Program at Kelsey Institute of Applied Arts and Sciences, Saskatoon. This species was collected in the Frenchman River (NE $1 / 4$ 33-4-17 W 3rd) from a pool of slow moving water on the north side of a high bank. Very little vegetative growth was present in the river and at this point and the bottom was composed mainly of mud and a few large stones.

Previous distribution records for this species in the prairie region of Canada indicate its presence only in the Red River as far north as Winnipeg, Manitoba and in the Milk River (Missouri River drainage) of southern Alberta. The Frenchman River in Saskatchewan is also part of the Missouri River system since it flows into the Milk River in Montana.
The stonecat can be distinguis from most other members of family Ictaluridae by the presence an adnate adipose fin (low ridge forward extension of the caudal The much smaller tadpole mad also has this feature. Other diagne characters of the stonecat premaxillary tooth patch with lat extensions (lacking in tadpole $n$ tom), square caudal fin, and b coloration strongly countersha dark above, yellow to white belc

The three specimens of ston collected from the Frenchman $R$ in 1975 measured 85,113 and 154 total length. One specimen is in personal collection of Mr. Ander a second is in the fish collection a Saskatchewan Fisheries Laborato Saskatoon and the third is in the collection at Kelsey Institute, $\mathrm{Sa}$ toon, Saskatchewan."

BROWN, C. J. D. 1971. Fishes of Mon Big Sky Books, Montana State Bozeman, Montana.

FEDORUK, A. N. 1971. Freshwater fist Manitoba: Checklist and keys. Man Dept. Mines, Res. and Envir. Manag

SCOTT, W. B. and E. J. CROSSMAN. Freshwater fishes of Canada. Bull. Fish. Res. Bd. Canada. Ottawa. 